\title{
Empirical analysis of corporate governance in transition
}

\author{
Wendy Carlin \\ University College London
}

Introduction

The practical problem of trying to understand the transition has focused attention on the nature of the firm in a capitalist economy and on the role of corporate governance in catch-up growth and for economic performance more generally. The limited capacity of economic theory to provide an explanation for the different patterns of ownership and control of companies across mature market economies is matched by the relatively small volume of empirical research investigating the relationship between the structure of ownership and control and performance.

It is possible that in time, the experience of transition economies will provide vital 
information for the development of a coherent theory of ownership and control. A common marketization shock has been imposed on existing enterprises in more than two dozen countries. A great variety of privatization methods have been adopted within and across countries (see EBRD (1997) Table 5.7) creating the basis for the analysis of the performance of firms with different ownership structures at a point in time as well as that of firms as they move from one ownership category to another over time.

The aim of this paper is to take stock of the state of research that analyses enterprise sector restructuring, the emergence of post-privatization structures of ownership and control and their implications for performance. The first part of this paper sets the scene by presenting a selective survey of recent literature from outside transition studies addressing the issue of corporate governance and its role in economic performance. Section 2 turns to the transition economies and presents a simple two stage framework into which the bulk of the theoretical and empirical work on enterprise sector reform in transition can be fitted. In stage one, the marketization shock occurs and its implications for enterprise restructuring are examined; in stage two, privatization occurs and the implications for performance of the post-privatization ownership structure are investigated. Section 3 takes up the issue of empirical testing by reviewing the evidence on post-privatization performance. Attention is given to what can be learnt about the process of privatization as well as about its effects through the proper statistical treatment of the problem of selection implicit in comparing results from different types of privatization. Section 4 draws the results from the western and transition literatures together. 


\section{Setting the scene: corporate governance in market economies}

Table 1 presents a summary of some recent approaches to the study of corporate governance in market economies. The majority of the discussion of corporate governance in transition economies, with its emphasis on the problems of managerial entrenchment and the paucity of external finance for investment, has been conducted along the lines of Shleifer and Vishny. Their definition of corporate governance is a narrow one. They see it purely in the context of the problem of the supply of external finance to firms. An agency model is used where the firm is a private body defined by a set of principal-agent relationships. Different systems of ownership are represented by different dominant principal-agent problems: a system characterized by dispersed ownership is one in which the owner-manager relationship presents the central corporate governance problem; in a system characterized by concentrated ownership, the key problem is that between the large shareholder and minority investors. In each case, external finance will only be provided by respectively outside or minority investors if the manager or the large shareholder can commit not to exploit their private benefits of control. These private benefits range from outright theft to empire-building to staying on the job when they are incompetent (Shleifer \& Vishny 1997).

Shleifer and Vishny propose that a functional system of corporate governance will be one in which there is ownership concentration to enforce profit-seeking behaviour - this will be straightforward in a system with a large shareholder but will occur through the 
mechanism of the hostile takeover in a system with no controlling shareholder. The other requirement for efficiency is that the legal rights of suppliers of external finance be protected. They suggest that the demands on the legal system are less in the case of concentrated ownership through a large share-holder. Indeed they suggest that for most countries the demands on the legal system of the dispersed ownership model are too heavy to be attainable. Hence in practical terms, only the large share-holder model is likely to be available for most countries and reform efforts should concentrate on improving legal protection for suppliers of debt and equity.

The study by La Porta, Lopez-de-Silanes, Shleifer and Vishny (1996) proposes a bolder hypothesis and one that has been less prominent in transition debates. They suggest that a key determinant of access to external finance in a country is its legal code. Legal codes divide into common law (UK, US, ex-Commonwealth countries) and civil law types. Three variants of civil code are the German (German-speaking and several East Asian countries), Scandanavian and French. They classify 49 countries according to legal code and gather detailed information on investor protection, enforcement and ownership concentration. The data suggest that an explanation for the rather low ownership concentration in common law countries is the greater degree of investor protection. They hypothesize that this increases the access of firms to external finance.

At the other extreme are the French civil law countries with weakest investor protection and high ownership concentration. Interestingly they find that whilst poor countries systematically have weaker law enforcement, there is no correlation between per capita 
GDP of a country and the legal system of investor right protection. Hence as exemplified by France and Italy, it is possible to get rich in spite of having an unfavourable legal code - they mention in passing that part of Poland was influenced by the French legal code in the 19th century whilst Hungary and Czechoslovakia adopted the German civil code in the early 20 th century. 


\section{Table 1. Cross-country studies of corporate governance}
Starting point:
Key concepts:
Claims:

\begin{tabular}{|c|c|c|}
\hline \multicolumn{3}{|l|}{ 1. Shleifer \& Vishny } \\
\hline Definition of corporate & Agency problems (= exploitation of & Access to external finance \\
\hline governance as the external & the private benefits of control): & requires (1) concentrated \\
\hline finance problem. The quality & Owner versus manager; Large & ownership either through a \\
\hline of corporate governance & shareholders versus small & controlling stake or through the \\
\hline should provide an explanation & shareholders. & takeover mechanism; and (2) \\
\hline for why firms have access to & & legal protection of the suppliers \\
\hline external finance in some & & of external finance. \\
\hline \multicolumn{3}{|l|}{ countries but not others. } \\
\hline \multicolumn{3}{|l|}{ 2. La Porta et al. } \\
\hline Differences in legal protection & Legal traditions of civil law and & Historical origin of the legal \\
\hline of investors and differences in & common law, rights of investors and & system determines the level of \\
\hline finance and ownership across & enforcement of rights: do these & investor protection. Higher legal \\
\hline \multirow[t]{6}{*}{ countries. } & favour investors or managers? & protection (associated with \\
\hline & & common law rather than civil law \\
\hline & & systems) implies less need for \\
\hline & & ownership concentration which \\
\hline & & increases access to external \\
\hline & & finance and reduces capital costs. \\
\hline
\end{tabular}




$\begin{array}{llll}\begin{array}{l}\text { 3. Mayer } \\ \text { Stylized fact of similar patterns }\end{array} & \text { Ownership from within the corporate } & \text { Patterns of ownership and } \\ \text { of investment finance } & \text { sector (concentrated holdings) allows } & \text { control do not primarily affect } \\ \text { (overwhelming reliance on } & \text { committed owners to overcome the } & \text { sources of finance or methods of } \\ \text { retentions to finance } & \text { problem of externalities in control } & \text { disciplining poor managers. They } \\ \text { investment) but different } & \text { and sustains implicit contracts } & \text { may influence the kinds of } \\ \text { patterns of ownership and } & \text { between stakeholders. Ownership } & \text { activities (as indicated, for } \\ \text { control across advanced } & \text { outside the corporate sector fosters } & \text { example, by industry } \\ \text { market economies. } & \text { external evaluation of the use of } & \text { specialization) economies are } \\ & \text { assets and facilitates changes in use. } & \text { able to succeed in. }\end{array}$

Mayer's papers in this field ${ }^{1}$ have sought to provide empirical information about two issues central to the agency approach to corporate governance: the patterns of investment finance in advanced market economies and the mechanisms through which managers are disciplined in poorly performing companies. Empirical results from flow-of-funds analyses using aggregate data indicate that across the advanced countries, there is considerable similarity in the patterns of investment financing and perhaps even more striking, a very tiny use of new equity as a source of finance even in the US and the UK (e.g. Corbett \& Jenkinson 1997). In a comparison of investment finance in Germany, Japan, the UK and the US from 1970 to 1994, Corbett and Jenkinson show that whilst Japan can still be characterized as 'bank-financed' (although the share of investment financed by bank loans halved between the early 1970s and the early 1990s), contrary to

\footnotetext{
${ }^{1}$ Relevant papers include: Mayer (1990), Franks \& Mayer (1997), Franks, Mayer \& Renneboog (1997).
} 
stereotypes, bank finance has not played an important role in Germany over that period. Germany, the UK and the US are all mainly internally financed with market sources of finance playing a small (often negative) and declining role.

Turning to management discipline, in studies of poorly performing companies in the UK and in Germany, it is shown that there is a relationship between poor performance and management turnover. But in neither country was higher ownership concentration associated with higher management turnover in the presence of poor performance. Although there was an active market in blocks of shares in both countries they did not appear to perform a disciplinary function: they were not related to management turnover. These results cast doubt on the idea that concentrated ownership or changes in ownership are the mechanisms through which corporate governance, in the sense of imposing ex post monitoring on management, is exercised.

These results are in line with Kaplan's findings (1994a, b) that the disciplining of managers in terms of salary cuts and dismissal as performance of a company falls below a given threshold is quite similar in companies in the US, Germany and Japan. The major differences in ownership and control structures across these countries do not seem to produce differences in this aspect of the exercise of corporate governance.

Mayer emphasizes that ownership concentration, takeovers and changes in share stakes may have a rather different role than that of ex post monitoring. Assuming that effective ex post monitoring is in place, then the difference between a financial system with 
concentrated ownership by non-financial companies, another where banks play a major ownership role and a third where ownership of large companies is much more dispersed and hostile takeovers occur may be that each is able to sustain a different set of activities. For example, a committed owner may be necessary to induce investment in the relationship by complementary factors such as workers, suppliers or customers, as well as managers. Whereas Shleifer and Vishny emphasize the ability of large share-holders to exploit their position and expropriate other stakeholders, Mayer highlights the role of the commitment to the continuation of an activity that is represented by a large share-holder.

Although much remains unresolved, one way of viewing this debate is the following. There is a trade-off which different successful financial systems resolve in different ways. The trade-off is between on the one hand, encouraging commitment of the manager (in an entrepreneurial capacity) and of complementary factors to often irreversible investments in human capital, and the dangers of large share-holders exploiting the private benefits of control. On the other hand a financial system which minimizes the possibility of large share-holder exploitation of other parties is unable to take full advantage of long-term relationships and risks opportunistic behaviour by managers but can benefit from the ability to switch asset use quickly. ${ }^{2}$ However, to be successful at all, a financial system must first establish some threshold level of ex post monitoring of management.

\footnotetext{
${ }^{2}$ This is consistent with the arguments presented by, for example, Porter (1990) and Soskice (1994) that there may be an institutional basis for a country's competitive advantage.
} 
What can we conclude for the analysis of transition from this birds-eye view of the debate about the role of corporate governance in the market economies? Our understanding of how institutional arrangements interact with economic performance is still limited and until recently, most research has focused on corporate governance arrangements within 'successful' advanced economies or on comparisons between such economies. But there are a number of directions for empirical work in the transition economies that may help to resolve these questions in the longer run.

As noted in the introduction, interest in the role of ownership in transition means that we will certainly have a better description of the structure of ownership at the outset of the market economy period in these economies and of changes in ownership than has been the case anywhere else in the world. In countries beginning with a total absence of mechanisms for ex post monitoring of managerial performance by corporate governance institutions, the opportunity for learning about the characteristics of the threshold level of corporate governance is enormous. Especially in the case of poorly performing companies, analysis is needed of managerial turnover and sales of share stakes (also supervisory board composition and changes where there are two-tier boards).

2. A two-stage approach to the transition literature on restructuring and corporate governance

\subsection{Stage one: marketization shock and reactive restructuring}

A simple two-stage framework has emerged in the analysis of enterprise reform in 
transition. The first stage follows the change of regime from the planned economy to a market economy. The 'marketization shock' entailed the introduction of market forces in goods, services and factor markets. Price liberalization and macroeconomic stabilization to enable market signals to function formed part of the marketization package. War, the collapse of trading relationships without the proximity of alternative markets and the weakness of government help to account for the cross-country variation in the length of time between the marketization shock and the recovery of aggregate output (Åsland, Boone \& Johnson, 1996).

The concept of the soft-budget constraint has proved a remarkably powerful tool in the analysis of enterprise behaviour subsequent to the marketization shock. Budget softness is measured by the weakness of the link between an enterprise's financial performance and its command over current and capital resources. In the planned economy, there was no clear link from financial performance to managerial compensation or tenure. Exit of the enterprise through closure was not a route through which the manager could lose control. Equally the planner could not promise to reward managerial effort because the absence of an outside option for the manager (no managerial labour market, no private sector) meant that any incentive structure would lack credibility. The planner could not commit not to toughen the manager's target once good performance had been demonstrated. (Roland \& Sekkat 1996). The marketization shock reinstated the connection between financial performance and access to resources, introduced the possibility of exit of firms and allowed for the creation of new private sector activities. 
Irrespective of ownership changes, the marketization shock produced a wave of restructuring activity by the managers of state-owned enterprises. The tightening of the budget constraint by the withdrawal of ex post state subsidies had the effect of inducing managers to exert the effort to cut costs by shedding labour and to seek markets for output where the cost of the perceived threat of closure outweighed the effort required and the riskiness of restructuring. Case study evidence revealed enormous heterogeneity between enterprises in their responses but there appeared to be systematic components of the variation explicable in terms of the basic theory of restructuring in response to a hardening of the enterprise budget constraint (Carlin, Van Reenen \& Wolfe 1995). ${ }^{3}$

Interesting new insights into the stage one restructuring process have been provided by studies of former Soviet Union (FSU) countries. Barter transactions as a response to the collapse of output and input planning have persisted for much longer after the beginning of the reforms in some of these countries suggesting much deeper disruption to supply chains as a consequence of the collapse of previous trading arrangements than was the case in Central and Eastern Europe. The Baltics represent an interesting intermediate case indicating that both geographical proximity to Western European markets and a shorter period of Communist rule may have made the recreation of a market economy easier.

Two recent studies of Moldova and Georgia (Djankov 1997, Djankov \& Kreacic 1998) emphasize the persistence of the phase of disorientation and disorganization (e.g. Blanchard 1997 ch. 2) as managers of SOEs (or former SOEs) display passive

\footnotetext{
${ }^{3}$ For a survey of evidence on restructuring up to 1996, see Carlin \& Landesmann, 1997.
} 
behavioural responses of the kind documented by Carlin, Van Reenen \& Wolfe (1995).

In the face of virtual total absence of sales, younger workers have left enterprises yet the managers continued to hold on to capital equipment and other assets expecting orders to appear that would restore full capacity utilization without the need for them to take any action. In the Moldovan study, specific attention was paid to the possible role that training programmes for managers could play in inducing improved performance. A manager having attended a training programme was the biggest determinant of the extent to which the enterprise was engaged in market as opposed to barter transactions (Djankov 1997). The type of training appeared to make no difference to its effectiveness, which suggests that the training may have performed the function of introducing managers in this economy to some very basic notions of how a market economy operates.

Outside observers were often surprised by the speed with which reactive restructuring took hold in the leading transition economies. The speed of trade reorientation by the Central and East European countries was also frequently referred to as remarkable. This new evidence from the FSU highlights the possibility that the rapid reaction of enterprise managers in Central Europe may have been influenced by the diffusion of information about market economies through trade and FDI contacts and the return of emigres. The evidence from the countries studied most heavily in Eastern Europe suggested that an understanding of the changes in incentives associated with the marketization shock provided a good explanatory model for the observed pattern of behavioural responses by incumbent managers of SOEs. The late-reformers may provide new information about the 
role of managerial human capital and learning in the reform process. ${ }^{4}$

\subsection{Stage two: privatization and deep restructuring}

In the early transition literature, it was often claimed that privatization was probably necessary but not sufficient to elicit deep restructuring. The term 'deep restructuring' was used to refer to a second set of actions that enterprise managers would need to take, over and above those needed to break-even, in order to produce an efficient growth and profitoriented firm. The claim was based on the idea that once enterprises were operating under tight budget constraints, privatization could result in ownership structures that placed no constraints on managerial behaviour (in addition to those produced by competitive pressure, which would affect state-owned as well as privatized enterprises). Hence managers could continue to enjoy the private benefits of control of firms in the form of incumbency.

Nevertheless privatization was seen as an essential part of the process of depoliticizing enterprises: reducing dependence on state orders, on ex post government subsidies and on protection by the state from closure. In short, privatization was a way of locking-in the marketization shock and promoting reactive restructuring but would not automatically produce static and dynamic efficiency. Deep restructuring was normally assumed to require profit orientation as an objective of the owners that could be imposed on managers, the requisite human capital to identify profitable opportunities and the means

\footnotetext{
${ }^{4}$ An earlier study of Russian shops pointed in this direction (Barberis, Boycko, Shleifer and Tsukanova 1996).
} 
to implement (i.e. to finance) the associated investment.

A hierarchy of ownership structures ordered by their compatibility with deep restructuring has gained widespread currency in the literature. Outside ownership was typically viewed as preferable to inside ownership subject to the proviso that the outside ownership structure produced effective control over management. To this end the concentration of voting shares in the hands of an outside owner was viewed as the feasible structure. Because of the underdevelopment of the capital market, reliance on surveillance of performance by takeover raiders using verifiable public information on companies was not seen as a feasible structure of control in the presence of dispersed outside ownership.

Foreign owners were usually ranked first as profit-oriented owners with the requisite human and financial capital to push through deep restructuring. Less clear was the ranking between different types of domestic outside owners. Domestic strategic investors, banks and investment funds with controlling stakes were credited with different combinations of profit-orientation, human and financial capital resources and agency problems.

Of firms without an outside controlling owner, managerial ownership was identified as providing superior profit-orientation to that associated with worker-ownership. Workerownership could entrench the veto by workers over forms of restructuring that would threaten their jobs: this would depend on workers' perception of opportunities for employment or for income-support outside the enterprise. On the other hand, initial 
worker ownership could provide a route to deep restructuring via the ousting of an entrenched incompetent manager if there was a market for shares.

\section{Evidence on restructuring, privatization and corporate governance in transition}

The empirical investigation of ownership and performance using firm-level data sets has gathered pace in the last two years. The attempt to test for a causal connection from ownership structure to performance focuses attention on the question of how enterprises acquired their private owners. There are two interesting questions: first, did the characteristics of enterprises and their managers differ systematically across methods of privatization within and between countries and second, how has post-privatization ownership affected firm performance. Unfortunately there has been less attention given to the first than to the second question. We do not have a clear picture of how systematic the connection was between privatization methods and enterprise characteristics. For example, the typical assumption in the literature is that foreign ownership of former stateowned enterprises best facilitates the process of deep restructuring. But unless we know the characteristics of these enterprises, the conditions relating to post-privatization employment adjustment or investment attached to the sale, and how they were selected for foreign ownership, it is not possible to test this assumption.

There are two issues at stake in the analysis of selection effects. On the one hand, we are interested in finding out whether there was a difference in the observable characteristics of the enterprises which ended up receiving a different privatization 'treatment'. If the observable characteristics were different then we can assume that participants in the 
process could have known about them. However, a second issue arises if there were differentiating characteristics which were not observable in pre-privatization performance. The most obvious is the quality of management. From the literature on preprivatization restructuring, it is clear that the design of the privatization process could create incentives for managers to reveal or to conceal their quality prior to privatization. If some methods of privatization created an incentive for managers to reveal their quality whilst others led to concealment then the use of observable characteristics such as preprivatization performance would not capture this dimension of selection bias.

An understanding of whether privatization per se or particular methods of privatization selected enterprises by quality is important not only for the correct interpretation of the results of privatization but also for the broader evaluation of approaches to privatization across countries. Detailed trade information for manufacturing indicates that transition countries have varied considerably in their ability to move up product quality ladders with Hungary, the Czech Republic and Slovenia upgrading their exports much faster than Poland or Russia (Carlin and Landesmann 1997). An obvious question is whether privatization programmes have played any role in this. The dominant privatization method has been different in Hungary, the Czech Republic and Slovenia suggesting that country characteristics such as size and openness of the economy may dominate any privatization effect. But this simple interpretation neglects the possible role of privatization methods, since systematic selection of enterprises by quality could have occurred through different primary methods. 


\section{Did methods of privatization select enterprises by quality?}

In the general discussion of privatization, a particular method has sometimes been associated with the 'best' or 'higher quality' state-owned enterprises. In some cases, privatization design has sought deliberately to associate enterprise quality with a specific method of disposal. East Germany provides probably the clearest example of this intention. All core business activities of enterprises were evaluated for their potential viability and bids from outside investors sought by the privatization agency. Enterprises viewed as potentially viable but for which there was no outside investor interest could be disposed of through MBOs; non-viable enterprises were slated for rapid closure. By prioritizing direct sales, the Hungarian and Estonian privatization programmes followed a policy similar to that in East Germany. Both countries pursued more decisive closure/ bankruptcy programmes than was typical elsewhere.

In Poland, typical descriptions of the privatization programme indicate that apart from the small number of large firms picked out for public offer in the early show-case privatizations, the best enterprises were acquired by managers through MBOs. Accounts of Russian privatization stress that the priority was speed and that the lack of information available to outside investors, the weakness of the legal framework for the protection of their rights and the control by insiders over the selection of the method of privatization were likely to result in dominant stakes in the best firms being acquired by insiders.

There are now a number of studies that provide information on selection and make explicit their attempt to deal with the selection problem in the analysis of post- 
privatization performance. The studies considered here provide information on mediumsized firms in Poland, Hungary and the Czech Republic (Frydman, Gray, Hessel and Rapaczynski, 1997), on large Polish firms (Grosfeld \& Nivet, 1997), on the sample of Czech firms included in the large privatization programme (Marcincin \& van Wijnbergen 1997) and on a representative sample of Russian firms (Earle \& Estrin, 1997).

Contrary to the frequent claims in the literature, Grosfeld and Nivet failed to confirm that privatized large Polish firms in their sample were stronger performers prior to privatization than were those that were commercialized or remained in state ownership. Frydman et al. also failed to find any systematic difference in the observable preprivatization performance and characteristics in their sample of medium-sized firms between those that remained in state-ownership and those that were subsequently privatized. However they did find that firms that were privatized to insiders i.e. to managers and workers were superior in their pre-privatization performance to those privatized by other methods. Earle and Estrin's results confirm the 'stylized fact' that the voucher privatization in Russia was biased against outsiders taking controlling stakes in the best firms.

One study that investigates this issue in depth refers to the Czech privatization process. A misleading impression has sometimes been given of the Czech privatization process when the role of other bidders prior to the disposal of shares through the voucher auctions is neglected. About one half of property in the 'large privatization' programme (amounting to about one-quarter of all property privatized) went through the voucher process rather 
than, for example, through direct sales, and of those firms, the voucher stake for the median company was $80-90 \%$ but only about $50 \%$ when firms are weighted by the size of their assets (Marcincin and Van Wijnbergen, 1997).

The model used in this paper centres on the simple idea that enterprises can either be privatized through a method that produces dispersed ownership or one that produces concentrated ownership. The latter is assumed to be superior in terms of generating rapid restructuring. However, the government, with its eye on electoral support, is constrained in its choice of method by the need for speed so as to enhance the credibility of the programme and by the fact that the number of investors available in a short period is limited. Restructuring potential depends both on observable and unobservable characteristics and the government is assumed to choose the privatization method for each enterprise based on observable restructuring potential, increasing the probability that the better enterprises would be privatized via the second method.

By using a two stage estimation process to separately identify the selection effect, Marcincin and Van Wijnbergen found support for the hypothesis that the firms sold wholly through vouchers were of lower quality than those for which vouchers comprised only a part of the disposal. This is an important finding in its own right: showing that a privatization process with a tight dead-line was able to sort enterprises by quality. It also raises interesting questions about the role of managerial consent to outside ownership and casts doubt on the claim that voucher privatization in the CR to outsiders was only possible because managers expected that dispersed ownership would result and that they 
would retain control. An interesting possibility is that the better firms prior to

privatization were those with better managers who at the privatization stage were willing to exchange control for access to finance that could be facilitated through an outside strategic investor.

The feature of the Czech voucher process of combining speed with selection of 'better' enterprises into 'better' ownership structures may prove to be important in understanding the consequences of voucher privatization in a comparative setting, alongside the more widely discussed cross-country differences in ownership of voucherized firms. As noted above the opposite selection of 'better firms' into 'worse' ownership structures was confirmed by Earle and Estrin as the outcome of Russian voucher privatization.

\section{Does privatization matter for performance? Does ownership structure matter for post-privatization performance?}

Recent work has shown the benefits of using different approaches to uncovering the impact of privatization. Frydman et al. (1997) argue for example that valuable information may be gleaned by separating the cost reduction and revenue increasing components of profitability. They suggest that reactive restructuring would be captured by cost-cutting but signs of deep or strategic restructuring would be reflected in revenue increases. Accounting profitability may be a poor discriminator because of the possibilities for the manipulation of recorded costs in order to minimize tax liabilities and the possibility that manipulation may be systematically related to profit-orientation and managerial ability. Their hypothesis is that all firms will display reactive restructuring in 
the face of the marketization shock but that privatized ones will be marked by superior revenue growth performance in the post-privatization period as compared with firms that remain in state ownership.

Some caution is needed in interpreting the results because of the remaining methodological problems and the very small sample sizes once ownership is divided into seven categories (e.g. there are ten or less firms in four of the categories). Although country dummies are included, the fact that some forms of ownership occur only in one country means that there will be a confounding of the country and the ownership effect (e.g. all firms owned by a privatization fund are Czech and all worker-owned firms are Hungarian). Subject to these serious caveats, the performance of the medium-sized firms in the Frydman et al. sample appear to differ according to their new ownership structure. Concerns about selection bias are lessened by the finding, noted above, that there was no difference in observable pre-privatization performance between privatized firms and SOEs. The superior pre-privatization performance of insider-owned as compared with outsider-owned firms allays the concern that managers seeking to secure ownership on favourable terms had an incentive to conceal capabilities prior to privatization.

Taking their preferred performance variable - revenue growth - privatized firms outperformed SOEs. Differentiating privatized firms by the dominant owner, then the best performers were firms owned by privatization funds, by foreigners and by managers. Strikingly, partially privatized firms with the state as the largest share-holder showed a similar revenue growth performance to this group. However, further investigation 
revealed that firms in this group performed in line with those owned by their second largest owner, suggesting a passive role of the state in partially privatized firms. Weaker performance indistinguishable from that of SOEs was shown by the small sample of firms with a domestic non-financial institution owner and by worker-owned firms.

These results appear to provide some support for the prediction that employee-ownership in transition would slow down the restructuring process. Such firms display less costcutting and labour-shedding than do SOEs and show no better growth of revenue. Manager-owned firms seem to be just as entrepreneurial as fund or foreign-owned ones but shed less labour than do SOEs thus failing to register a superior productivity performance. The achievement of manager-owned firms is also diminished somewhat by the finding that the performance of insider-owned firms was better than that of other firms before privatization.

For the much larger sample of Czech firms, Marcincin and Van Wijnbergen showed that after correcting for the selection bias, the observed post-privatization performance of fully voucherized firms was weaker, confirming the hypothesis that outside ownership matters for performance.

The most detailed study of Russian privatization using enterprise level data is provided by Earle and Estrin (1997) in an exhaustive examination of the characteristics of a representative sample of about 300 'old' enterprises immediately after the completion of voucher privatization in mid 1994. Using their results, the structure of initial ownership 
following the privatization programme in Russia can be summarized in Table 2 .

Following mass privatization, the role of the state remained considerable: considering all 'old firms', the proportion of employment in firms in which the state remained a dominant owner (with a stake of at least $40 \%$ ) was $38 \%$. Just looking at firms that were at least partially privatized, one fifth of employment was in firms with the state as the dominant owner after privatization. Of those with a dominant private owner, over 70\% were in insider-dominated firms and three-quarters of those were in worker rather than manager-dominated firms.

Table 2 shows that the ownership outcomes differed according to the method of privatization used. Insider-ownership was far more prevalent with both leasing privatization (lease buy-outs to workers that occurred before the main privatization programme) and with the selection of Option 2 privatization (through which employees secured $51 \%$ of shares at 1.7 times the book value of the firm). These two methods accounted for $70 \%$ of the firms privatized. The dominance of insider ownership is clear but was not uniform across privatization methods.

Whilst less than one in ten firms had a dominant outside owner, one in four had an outside blockholder with a stake of at least $25 \%$. More detailed analysis provided support for anecdotal reports that banks and 'other firms' were often not true outsiders: their presence as outsiders was most common where insiders were dominant in the firm. By contrast, investment funds appeared to gravitate toward firms where insiders did not have a majority (e.g. in Option 1 companies through which insiders received 25\% of shares 
free and could purchase up to $15 \%$ more at nominal prices). For a given insider stake, the preference of investment funds was revealed to be for blocks in companies that were not dominated by manager-owners.

To get around the problem of the endogeneity due to the possible selection bias in privatization, Earle and Estrin proposed the use of the method of privatization as an instrument exploiting the correlation between privatization method and ownership structure in an instrumental variables approach to estimating the relationship between ownership structure and performance. They used a multi-dimensional restructuring index (capturing mainly reactive restructuring) and labour productivity as their performance variables. They found that privatization was associated with a very small but significant positive effect on performance. Managers as owners produced a larger impact. Whilst outside ownership appeared to have no significant effect on performance in the OLS regressions, it did in the IV specifications providing support for the idea that weaker firms were available to outside owners. Evaluation of these results is difficult because of the fact that the survey was conducted immediately after the privatization process. 
Table 2. Post-privatization ownership and privatization methods in Russia (from Earle \&

Estrin, 1997)

\begin{tabular}{|c|c|c|c|c|c|c|}
\hline \multirow[b]{2}{*}{$\begin{array}{l}\text { Dominant } \\
\text { owner }\end{array}$} & \multicolumn{3}{|c|}{$\begin{array}{l}\text { Post-privatization Ownership Structure } \\
\text { (by dominant owner) }\end{array}$} & \multicolumn{3}{|c|}{ Methods of Privatization } \\
\hline & All old firms & $\begin{array}{l}\text { At least partially } \\
\text { privatized }\end{array}$ & $\begin{array}{l}\text { At least partially } \\
\text { privatized }\end{array}$ & Leasing & Option 1 & Option 2 \\
\hline & \multicolumn{2}{|c|}{$\begin{array}{c}\% \text { of firms weighted by } \\
\text { employment }\end{array}$} & \multicolumn{4}{|c|}{$\%$ of firms (unweighted) } \\
\hline State & 38 & 20 & 8 & 1 & 21 & 4 \\
\hline Private & 62 & 80 & 92 & 98 & 78 & 96 \\
\hline - Insider & 45 & 59 & 77 & 95 & 51 & 81 \\
\hline - - worker & 35 & 44 & 51 & 71 & 34 & 49 \\
\hline - - manager & 6 & 8 & 15 & 21 & 8 & 15 \\
\hline - - other & 4 & 5 & 10 & 0 & 9 & 15 \\
\hline - Outsider & 9 & 12 & 9 & 3 & 12 & 11 \\
\hline - Other & 7 & 9 & 6 & - & 14 & 5 \\
\hline No. of firms & 327 & 241 & 238 & 66 & 65 & 104 \\
\hline
\end{tabular}

Note: The firms privatized according to Option 3 (an MBO based on a performance contract) are omitted because there were only 3 cases in the sample and it was of negligible importance in the privatization programme.

Source: Estrin \& Earle (1997) Tables 4, 5, 14.

In a very different approach, Grosfeld and Nivet examined the behaviour of a sample of large Polish firms over a lengthy period that includes pre-reform data. Their sample selection criteria dictated a quite specific sample, namely firms that were present 
continuously from 1988 to 1994 . By comparing the average performance of sample firms, which accounted for between one-quarter and one-third of manufacturing output over the sample period, with the industrial sector of the economy as a whole, it is clear that these represented the block of large firms that have been slow to privatize (only $16 \%$ privatized by 1994) and where the recovery of output has been delayed (no output growth by 1994 compared with the rise in aggregate industrial output from 1992).

The focus of the paper is on wage-setting behaviour and on investment. An examination of wage-setting provides a useful method of gathering information as to the objectives of the firm and helping to identify the dominant decision-making parties. By using a wage equation that includes firm-specific and industry variables it is possible to examine the extent to which changes in wage reflect rent-sharing as compared to the conditions external to the firm such as the industry wage or the regional unemployment rate. This provides an indication of how the balance of power is distributed between different agents in the firm. The greater is the power of workers, the weaker the influence of external conditions on the wage that is paid and the larger the extent to which workers would be expected to capture the gains from productivity increases. An entrepreneurial firm seeking to maximize profits in order to maximize the availability of internal funds to finance investment or to distribute profits so as to improve its access to market funds would be expected to display less rent-sharing with wages tied more closely to the industry wage or unemployment.

Because of the sample used, Grosfeld and Nivet have rather few privatized firms (24 of 
the 173 firms in 1994) and they focus on the distinction between SOEs, commercialized/ corporatized former SOEs and privatized firms. Most of the latter were privatized to strategic investors or by public offer. There is no overlap between the Polish firms in this sample and the much smaller ones investigated by Frydman et al. Their results support the hypothesis that commercialization represented a breaking down of the power of workers in SOEs: they found that insiders captured the bulk of the productivity gains in SOEs but that the link from firm-specific productivity to the wage was much weaker in commercialized enterprises. In the privatized firms, there was no positive effect of firmspecific productivity gains on wages - indeed the data suggested that far from sharing firm-specific productivity gains with employees, there was a negative impact pointing toward the vigorous attempt of managers to widen profit margins.

Investment has been regarded as a defining characteristic of deep restructuring. Hence there is interest in the question of whether the amount of investment (e.g. investment as a percentage of value-added) differs systematically between state-owned and privatized firms and between firms of different ownership types. Secondly, the analysis of investment behaviour can, in a similar way to that of wage-setting behaviour, throw light on managerial motivation and profit-orientation. Grosfeld and Nivet estimated an investment equation including accelerator and cash-flow terms along with ownership dummies. They found that only the ownership dummies were significant. Thus it appears that differences in ownership dominated the standard determinants of investment. In particular, the predicted ranking that privatized firms would invest most (almost twice the sample mean) followed by commercialized ones, which in turn would invest more than 
SOEs was confirmed. This is consistent with the differences in wage behaviour: the absence of rent-sharing with employees in the privatized firms indicated strong profitorientation; the investment equation confirms that this was reflected in higher investment.

In a second analysis, an investment function was estimated for each ownership group separately. For each group, lagged profits were a significant determinant of investment but sensitivity to the profits variable was much greater for the privatized firms. Only for the SOEs was the output growth term significant. An interpretation favoured by the authors is that by comparison with privatized firms, investment in SOEs was influenced by the short-term evolution of sales. The strong role of the cash-flow variable for privatized firms could reflect financing constraints or it could be a proxy for expectations perhaps indicating that current profitability is seen as a better indicator of prospective profitability than is recent growth of output.

Grosfeld and Nivet's results for very large Polish firms demonstrate a clear difference in behaviour between those still in state ownership and those that had been privatized (see Table 3 for a summary). Commercialization emerged as an effective strategy for wresting control from employees. The investment behaviour of commercialized firms was more similar to that of privatized firms than to SOEs. The dimension on which privatized firms stood out most clearly from the rest was in output growth. Growth performance was not only stronger but the growth of output of privatized firms was much less influenced by sectoral output growth than was the case for other types. This is fully consistent with the more 'entrepreneurial' behaviour of privatized firms observed by Frydman et al. About 
half of the privatized firms had a strategic outside owner and the other half were sold through public offer. The finding of deep restructuring behaviour in this group highlights the need to find out more about the ownership and control structure of these privatized firms. 
Table 3. Investment in large Polish firms 1992-4: results from Grosfeld \& Nivet (1997)

\begin{tabular}{|c|c|c|c|}
\hline & \multicolumn{2}{|c|}{ State-owned } & \multirow[t]{2}{*}{ Privatized } \\
\hline & SOEs & Commercialized & \\
\hline No. of firms (1994) & 85 & 61 & 27 \\
\hline $\begin{array}{l}\text { Average } \\
\text { employment }(2,613)\end{array}$ & & & \\
\hline $\mathrm{I} / \mathrm{Y}(\%)$ & 4.8 & 6.0 & 11.2 \\
\hline $\begin{array}{l}\text { Coefficient on } \\
\text { accelerator term }\end{array}$ & 0.026 & Not significant & Not significant \\
\hline $\begin{array}{l}\text { Coefficient on } \\
\text { profits term }\end{array}$ & 0.146 & 0.289 & 1.025 \\
\hline
\end{tabular}

Note: Coefficients are significant at $5 \%$ or at $1 \%$. Not significant means not significant at $10 \%$.

Source: Grosfeld \& Nivet (1997) p.4, Tables 6, A2.

The emerging picture of a clear effect of privatization on deep restructuring, with outsider owned firms showing superior performance and worker-owned firms failing to outperform SOEs is not fully confirmed by a detailed study of the investment behaviour of Czech firms. Lizal and Svejnar (1998) examined investment in a large sample of Czech firms over the period 1992 to 1995 . Their descriptive data did show that foreignowned firms had the highest investment shares and cooperatives the lowest. However, private limited liability companies and those owned by private individuals had fairly low investment levels throughout the period - certainly not clearly any higher than for SOEs. 
Both private and state joint-stock companies had higher (and fairly similar) investment levels.

Unlike the studies of Frydman et al. and Grosfeld and Nivet, the Czech data-set includes new start-up firms - although the cut-off point of more than 25 employees (and more than 100 employees in the final year sample) excludes the small de novo firms. Any de novo firms included in the data will tend to be in the lower size classes and in the legal forms of limited liability and individually owned. As noted above, these firms have shown relatively low investment levels and the behavioural equations suggest that investment in the large category of limited liability was hampered by financial constraints. Apart from these smaller private firms and cooperatives, the Czech data suggests that financial constraints as proxied by a cash-flow term did not play an important role in determining investment levels. Instead, it was the accelerator term that seemed more often to be important. Taking joint stock companies, whilst the accelerator term was significant for state and foreign owned ones, investment in those privately owned was not systematically related to either the growth of sales or past profits. As an illustration of the results, Table 4 below shows the results for the investment equation for 1995 for state-owned, private and foreign-owned firms. 
Table 4. Investment in Czech firms in 1995 from Lizal \& Svejnar (1998)

\begin{tabular}{|c|c|c|c|c|c|c|c|c|}
\hline & \multicolumn{3}{|c|}{ State-owned } & \multicolumn{3}{|c|}{ Private (domestic) } & \multicolumn{2}{|c|}{ Foreign-owned } \\
\hline & SOE & $\begin{array}{l}\text { Joint- } \\
\text { stock }\end{array}$ & Limited & $\begin{array}{l}\text { Joint- } \\
\text { stock }\end{array}$ & Limited & Indiv. & $\begin{array}{l}\text { Joint- } \\
\text { stock }\end{array}$ & Limited \\
\hline No. of firms & 125 & 725 & 25 & 218 & 648 & 36 & 48 & 111 \\
\hline $\begin{array}{l}\text { Mean } \\
\text { employment }\end{array}$ & 327 & 823 & 845 & 486 & 242 & 198 & 912 & 358 \\
\hline $\mathrm{I} / \mathrm{Y}(\%)$ & 7.2 & 19.6 & 21.1 & 17.7 & 8.6 & 5.9 & 16.8 & 24.2 \\
\hline $\begin{array}{l}\text { Long-run } \\
\text { coeff. on } \\
\text { accel. term }\end{array}$ & .012 & .073 & N/A & .040 & .090 & $\begin{array}{l}\text { Not } \\
\text { sign. }\end{array}$ & .237 & $\begin{array}{l}\text { Not } \\
\text { sign. }\end{array}$ \\
\hline $\begin{array}{l}\text { Long-run } \\
\text { coeff. on } \\
\text { profits term }\end{array}$ & $\begin{array}{l}\text { Not } \\
\text { sign. }\end{array}$ & $\begin{array}{l}\text { Not } \\
\text { sign. }\end{array}$ & N/A & $\begin{array}{l}\text { Not } \\
\text { sign. }\end{array}$ & .056 & $\begin{array}{l}\text { Not } \\
\text { sign. }\end{array}$ & $\begin{array}{l}\text { Not } \\
\text { sign. }\end{array}$ & $\begin{array}{l}\text { Not } \\
\text { sign. }\end{array}$ \\
\hline
\end{tabular}

Note: Number of firms is approximated by number of observations divided by four. Less observations were available for the regressions. Coefficients are significant at $5 \%$ or at $1 \%$. Not significant means not significant at $10 \%$.

Source: Lizal \& Svejnar (1998) Tables 6, A2, A7.

Tables 5 and 6 below summarize the results from these five studies - showing firstly the results for selection, privatization and ownership effects and secondly for evidence of differences in behaviour indicative of profit orientation and deep restructuring. These studies suggest that firms partly privatized in which the state has a substantial share- 
holding perform better than SOEs. There is some indication that the state may be passive since firms tend to behave like those owned by the second largest owner. The need for further investigation of partial privatization, including of Czech firms is indicated. All studies point toward worker-owned firms as performing weakly and often indistinguishably from SOEs. The interesting issue of whether worker-ownership facilitates the transfer to outside owners is not addressed directly in any of these studies but the tendency for worker-ownership to go together with outsider block-holdings in Russian firms points in this direction.

Some signs of entrepreneurial behaviour by managers as owners were identified. The samples contain little information about foreign-owned firms and although there is some indication that banks as owners have proved less effective than other financial institutions, the evidence is thin. 
Table 5. Summary of results: Selection, privatization and ownership

\begin{tabular}{|c|c|c|c|c|}
\hline & $\begin{array}{l}\text { Poland, Hungary, } \\
\text { Czech Republic } \\
\text { (Frydman et al) }\end{array}$ & $\begin{array}{l}\text { Czech Republic } \\
\text { (Marcincin \& Van } \\
\text { Wijnbergen) }\end{array}$ & $\begin{array}{l}\text { Poland } \\
\text { (Grosfeld \& } \\
\text { Nivet) }\end{array}$ & $\begin{array}{l}\text { Russia } \\
\text { (Earle \& Estrin) }\end{array}$ \\
\hline Sample description & $\begin{array}{l}\text { Medium-sized } \\
\text { firms:1990-92 } \\
\mathrm{E}=360\end{array}$ & $\begin{array}{l}\text { 'Large privatization' } \\
\text { sample, } 1991-95\end{array}$ & $\begin{array}{l}\text { Large firms } \\
\text { only: } 1988-1994 \\
\mathrm{E}=2613\end{array}$ & $\begin{array}{l}\text { Representative } \\
\text { sample, mid } 1994\end{array}$ \\
\hline Number of firms & 178 & 560 & 173 & 327 \\
\hline \multicolumn{5}{|l|}{ 1. Selection } \\
\hline $\begin{array}{l}\text { Were better firms } \\
\text { privatized? }\end{array}$ & No & N/A & No & N/A \\
\hline $\begin{array}{l}\text { Of privatized } \\
\text { firms, was pre- } \\
\text { priv. performance } \\
\text { better for insider } \\
\text { than outsider? }\end{array}$ & Yes & N/A & N/A & Yes \\
\hline $\begin{array}{l}\text { Were other } \\
\text { selection effects } \\
\text { found? }\end{array}$ & & $\begin{array}{l}\text { Yes: pre-priv., fully } \\
\text { voucherized worse } \\
\text { than partly } \\
\text { voucherized }\end{array}$ & & \\
\hline \multicolumn{5}{|c|}{ 2. Privatization effect } \\
\hline $\begin{array}{l}\text { Did privatized } \\
\text { firms perform } \\
\text { better than SOEs? }\end{array}$ & Yes & N/A & Yes & Yes (small effect) \\
\hline 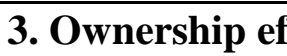 & & & & \\
\hline
\end{tabular}




\begin{tabular}{|c|c|c|c|c|}
\hline Better owners & $\begin{array}{l}\text { than SOE: } \\
\text { privatization fund; } \\
\text { foreign co.; } \\
\text { managers; part- } \\
\text { privatized }\end{array}$ & $\begin{array}{l}\text { some strong outside } \\
\text { ownership }\end{array}$ & N/A & $\begin{array}{l}\text { than SOE: } \\
\text { manager; } \\
\text { outsider (incl. } \\
\text { banks \& invest. } \\
\text { funds) }\end{array}$ \\
\hline Worse owners & $\begin{array}{l}\text { no better than } \\
\text { SOE: } \\
\text { worker; } \\
\text { domestic non- } \\
\text { financial co. }\end{array}$ & fully voucherized & N/A & $\begin{array}{l}\text { than SOE: } \\
\text { dispersed outsiders }\end{array}$ \\
\hline
\end{tabular}

Table 6. Summary of results: behaviour of firms

\begin{tabular}{|c|c|c|}
\hline & Poland (Grosfeld \& Nivet) & $\begin{array}{l}\text { Czech Republic (Lizal \& } \\
\text { Svejnar) }\end{array}$ \\
\hline Sample description & $\begin{array}{l}\text { Large firms only: } \\
E=2613,1988-1994\end{array}$ & $\begin{array}{l}\text { Population of med.\& large firms, } \\
1992-95\end{array}$ \\
\hline Number of firms & 173 & $>2,000$ \\
\hline \multicolumn{3}{|l|}{ 1. Investment behaviour } \\
\hline $\begin{array}{l}\text { Do privatized firms invest more } \\
\text { than SOEs? }\end{array}$ & Yes & $\begin{array}{l}\text { Yes if foreign owned; but } \\
\text { investment is low for some types } \\
\text { of private }\end{array}$ \\
\hline $\begin{array}{l}\text { Is investment behaviour different } \\
\text { for private compared with SOEs? }\end{array}$ & Yes & No clear pattern \\
\hline \multicolumn{3}{|l|}{ 2. Wage-setting behaviour } \\
\hline $\begin{array}{l}\text { Do privatized firms display more } \\
\text { profit-oriented wage-setting? }\end{array}$ & Yes & N/A \\
\hline
\end{tabular}




\section{Corporate governance in transition economies: unanswered questions}

As this survey of recent work investigating ownership, enterprise behaviour and performance in transition economies has made clear, systematic econometric study is at an early stage. Many more studies with different samples and from different countries will need to accumulate before we can feel confident that the results so far are reliable. It is striking that each study presented here has taken a different approach to dealing with the selection bias/ endogeneity problem - even with these data-sets, replication using different methods is called for. The brief mention of recent studies focusing on reactive restructuring in FSU countries highlighted the possibility that the late and more slowmoving reformers may provide new information on the consequences of the marketization shock and the role of human capital and learning in the adjustment to the market economy.

Most of the analysis of corporate governance and enterprise sector reform to date in transition has sought to identify the impact of changes in property rights or differences in ownership structures on the behaviour of individual firms. Less attention has been paid to developing an understanding of how well the corporate governance system in the economy as a whole has developed. This is not surprising in the light of the discussion in section two, which reported that there is no clear consensus regarding the threshold characteristics of an effective system of corporate governance. Whilst some authors suggest that in market economies with effective systems of corporate governance, the different structures of ownership and control provide a different mix of governance via ownership concentration and legal protection of investors, others point to the apparent 
similarity of financing patterns and triggers for disciplining managers. They hypothesize that differences in ownership and control structures across countries are linked less to ex post monitoring of managers and more to identifying the kinds of activities each financial system best supports. We need, for example, to understand what it is that produces the disciplining of managers at similar levels of performance in such disparate ownership and control systems as Japan, Germany and the US.

In transition economies, the careful monitoring of institutional developments in the legal code and its enforcement (including bankruptcy), the role of external finance in investment, the nature of bank finance and of bank-firm relationships and the concentration of ownership in the economy as a whole should be pursued alongside the analysis of individual enterprise behaviour. We need to begin to utilize the information from firm-level studies in conjunction with country-level characteristics, to assemble the bigger picture of the systems of corporate governance that are evolving. The systematic study of the large group of transition economies may eventually throw light on puzzles like the relative success of Italy in post-war catch-up growth in spite of its very poor financial system (poor legal code, lack of financial institutions to impose ex post monitoring, lack of mechanisms to shift resources to different uses) and the relative failure of the UK in catch-up growth despite its apparently more efficient financial system. 


\section{References}

Åsland, A., P. Boone \& S. Johnson (1996). 'How to stabilize: lessons from postcommunist countries' Brookings Papers on Economic Activity 1, pp. 217-313.

Barberis, N., M. Boycko, A. Shleifer \& N. Tsukonova (1996). 'How does privatization work? Evidence from Russian shops' Journal of Political Economy 104(41) pp. 764-90.

Blanchard, O. (1997). The Economics of Post-Communist Transition Oxford: OUP.

Carlin, W. \& M. Landesmann (1997). 'From theory into practice? Restructuring and dynamism in transition economies' Oxford Review of Economic Policy Vol. 13, No. 2, pp. 77-105.

Carlin, W. , J. Van Reenen \& T. Wolfe (1995) 'Enterprise restructuring in early transition: the case study evidence' Economics of Transition Vol. 3 No. 4. 427458.

Corbett, J. \& T. Jenkinson (1997). 'How is investment financed? A study of Germany, Japan, the United Kingdom and the United States' The Manchester School (Supplement) Vol. LXV, pp. 69-93. 
Djankov, S. (1997). 'On the determinants of enterprise adjustment: evidence from Moldova' Mimeo. World Bank.

Djankov, S. \& V-G Kreacic (1998). 'Restructuring of manufacturing firms in Georgia: Four case studies and a survey' Mimeo. World Bank.

Earle, J.S. \& S. Estrin (1997). 'After voucher privatization: the structure of corporate ownership in Russian manufacturing industry' CEPR Discussion Paper No. 1736.

European Bank for Reconstruction and Development (1997). Transition Report 1997. London: EBRD

Franks, J. \& C. Mayer (1997). 'Ownership, control and the performance of German corporations' Mimeo. Said Business School, University of Oxford.

Franks, J., C. Mayer \& L. Renneboog (1997). 'Capital structure, ownership and board restructuring in poorly performing companies' Mimeo. Said Business School, University of Oxford.

Frydman, R., C. Gray, M. Hessel \& A. Rapaczynski (1997). 'Private ownership and corporate performance: some lessons from transition economies' C.V. Starr Center for Applied Economics, NYU, Economic Research Reports RR\#97-28 
Grosfeld, I. \& J-F Nivet (1997). 'Wage and investment behaviour in transition: evidence from a Polish panel data set' CEPR Discussion Paper No. 1726

Kaplan, S. (1994a). 'Top executives, turnover and firms performance in Germany', Journal of Law, Economics and Organization 10, No. 1, pp. 142-159.

Kaplan, S. (1994b). 'Top executive rewards and firm performance: a comparison of Japan and the United States' Journal of Political Economy. 102, No. 3 pp. 510-546.

La Porta, R., F. Lopez-de-Silanes, A. Shleifer \& R. Vishny (1996). 'Law and finance' NBER Working Paper No. 5661.

Lizal, L. \& J. Svejnar (1998). 'Enterprise investment during the transition: evidence from Czech panel data' CEPR Discussion Paper No. 1835.

Marcincin, A. \& S. van Wijnbergen (1997). 'The impact of Czech privatization methods on enterprise performance incorporating initial selection bias correction' CERT Discussion Paper No. 97/4

Mayer, C. (1990). 'Financial systems, corporate finance and economic development' in R. Glenn Hubbard (ed.) Asymmetric Information, corporate Finance and Investment Chicago: University of Chicago Press 
OECD (1996). Economic Survey of Japan, Paris : OECD

Porter, M. E. (1990). The Competitive Advantage of Nations London: Macmillan.

Roland, G. \& K. Sekkat (1996) 'Managerial career concerns, privatization and restructuring in transition economies' ECARE (Brussels) Mimeo.

Shleifer, A. \& R. Vishny (1997). 'A survey of corporate governance' Journal of Finance Vol. LII, No. 2, pp. 737-783.

Soskice, D. (1994). 'Advanced economies in open world markets and comparative institutional advantages: patterns of business coordination, national institutional frameworks and company product market innovation strategies' Mimeo. Wissenschaftszentrum Berlin. 